\title{
CZY BYLIŚMY W WOJNIE Z SOWIETAMI?!
}

Inwazja Armii Czerwonej miała nastąpić po wykonaniu „czarnej roboty” przez Niemców, pod pozorem pomocy Białorusinom i Ukraińcom. Stalin pod wpływem ponagleń Berlina zdecydował o przyspieszeniu realizacji planów, nie czekając na ostateczne załamanie się państwa polskiego, co nie przeszkadzało mu argumentować, że „,państwo polskie i jego rząd faktycznie przestały istnieć". To potwierdza, iż polityka sowiecka wobec Polski była spoza dyplomacji, prawa i zasad moralności w sferze stosunków międzynarodowych.

Stalin ostatecznie zdecydował się zaatakować Polskę prawdopodobnie I3 września, gdy agentura $^{1}$ doniosła o decyzji aliantów z Abbeville. Następnego dnia Woroszyłow i jego szef sztabu Szaposznikow podpisali dyrektywę o ześrodkowaniu wojsk sowieckich na pozycjach wyjściowych do wieczora I6 września. Tego dnia w Moskwie Stalin zawarł rozejm w wojnie toczonej z Japończykami².

Kierownictwo państwa polskiego nie miało złudzeń co do sowieckich intencji wobec Polski, ale żywiło przekonanie, że państwo sowieckie kierując się własnym interesem geopolitycznym pozostanie neutralne poza konfliktem³ i nie odważy się uderzyć na Polskę, związaną

\footnotetext{
1 „Człowiekiem Stalina” był Edouard Pfeiffer, sekretarz premiera Francji, Edouarda Daladiera. W pracy Goeffreya Robertsa pojawiła się teza, iż zmowa z 23 VIII między Moskwą a Berlinem nie miała charakteru rozbiorowego wobec Polski i dopiero około 7 IX 1939 r. rząd ZSSR podjął decyzję o interwencji w Polsce. Zadziwia nie tylko ocena faktograficzna, jak i poprawność polityczna struktury semantycznej (interwencja, a nie agresja). Decyzja ta miała być niezależna od wcześniejszych ustaleń, tylko po co były owe ustalenia z 23 VIII, o których natychmiast był doniósł ambasadzie amerykańskiej w Moskwie (także Francuzi i Brytyjczycy poznali treść moskiewskiego tajnego protokołu, ale nie uznali za stosowne poinformować najbardziej zainteresowanej strony polskiej) sekretarz tamtejszej ambasady niemieckiej, Hans von Herwarth. Bardzo niekonwencjonalnie krótkowzroczność aliantów, a zwłaszcza bezczynność sojuszniczej Francji oddał późniejszy marszałek Francji, Alphonse Juin: „Dlaczego nie zaatakowaliśmy natychmiast na naszym froncie, gdy wojska niemieckie rzuciły się na Polskę? Jakiż błąd niewybaczalny! Nakazywał to przede wszystkim honor. [...] Pozwoliliśmy zdruzgotać Polskę związaną z nami paktem sojuszniczym. [...] Cóż za hańba! [...] Z punktu widzenia strategii popełniliśmy błąd poważny i ciężki. Nie było ryzyka. Wszystkie niemieckie dywizje pancerne, z wyjątkiem jednej, były zajęte w Polsce. Niemcy nie mieli prawie żadnych sił przeciw nam. Był to moment rzucenia wojsk do ofensywy, złamania ich linii Zygfryda, która była tylko bluffem".

2 W lipcu-sierpniu 1938 r. nad jez. Chasan trwały walki między Japończykami i Sowietami, po zajęciu przez wojska Armii Czerwonej wzgórza Zaoziornaja. Sowieci, mimo przewagi, doznali porażki. Wprawdzie Moskwa ogłosiła propagandowy sukces, ale dowódca sowiecki, marszałek Wasilij K. Blucher, popadł w niełaskę i zapłacił życiem za przegraną. W maju i wrześniu 1939 r. nad rzeką Chałchyn-Goł siły sowieckie pod dowództwem G. Żukowa odniosły zwycięstwo nad Japończykami. W wyniku tego Japończycy zrezygnowali z ataków na ZSSR.

3 Stalin obawiając się, by Polacy za wcześnie nie skapitulowali (czekał aż wojna rozpali się na dobre, a losy wojny polsko-niemieckiej będą przesądzone) za pośrednictwem ambasadora sowieckiego w Polsce, Nikołaja Szaronowa, mamił władze polskie nie tylko neutralnością Moskwy, ale i gotowością dostaw sprzętu wojennego przez ZSSR; zresztą on sam zniknął 11 IX 1939 r. jako kontakt dyplomatyczny dla polskiego MSZ. O zagrożeniu ze strony Sowietów alarmowały raporty attaché wojskowego w Moskwie, płk. dypl. Stefana Brzeszczyńskiego, meldunki
} 
sojuszami z Francją i Wielką Brytanią oraz... Rumunią. Nie rozważano też wariantu „R + N”, gdyż ta alternatywa strategiczna nie miała żadnej racjonalnej, efektywnej polityki. To była wersja katastroficzna polityki i Polska nie była w stanie militarnie się jej przeciwstawić4. Marszałek E. Śmigły-Rydz - wbrew min. Józefowi Beckowi - zbliżenia Niemiec i Sowietów nie wykluczał, rozważał je przy różnych okazjach, m.in. podczas konferencji 7 marca I939 r. jako zawsze możliwe i mające swoje antecedencje w historii5. W polskim MSZ żywe były też obawy, czy niemiecko-sowiecki pakt nie wywoła rozluźnienia układów koalicyjnych polsko-francusko-brytyjskich, a nawet wycofania się państw zachodnich z aliansu6 ${ }^{6}$ Dominowało wszak przekonanie, że Moskwa podżega do wojny, ale będzie odwlekała własne zaangażowanie, by w najkorzystniejszym momencie wygrać możliwie najwięcej. Podobnie jak postrzegano, że czerwona Rosja jest groźniejsza jako aliant, niż jako wróg, bo wpływa na stosunki wewnętrzne?

I7 września między godz. I.00 a $2.00 \mathrm{w}$ nocy jednostki sowieckiej straży granicznej i regularne siły Armii Czerwonej przekroczyły granice Rzeczypospolitej. Nastąpiło to, zanim ambasador RP Wacław Grzybowski, uważający się za realistę i liczący się ze złymi wiadomościami w postaci wypowiedzenia paktu o nieagresji pod byle pretekstem, otrzymał o godzinie 3.00 nad ranem, czyli I.00 czasu środkowoeuropejskiego, notę uzasadniającą sowiecką akcję przeciw Polsce ${ }^{8}$.

Sowieci dokonując agresji złamali pięć podpisanych uprzednio traktatów międzynarodowych. Ambasador Grzybowski wykrzyczał Władimirowi Potiomkinowi, zastępcy Mołotowa, że jeżeli akcja sowiecka nastąpi, będzie to oznaczać czwarty rozbiór i zniszczenie Polski. O Polsce wobec Georgija Dymitrowa Stalin wyrażał się z niekamuflowanym uczuciem nienawiści: „Zniszczenie tego państwa w obecnej sytuacji oznacza istnienie jednego państwa faszystowskiego mniej. Cóż złego w tym, gdybyśmy w wyniku pogromu Polski rozszerzyli system socjalistyczny na nowe terytoria i nową ludność"

Naczelny Wódz, marszałek Edward Śmigły-Rydz, który I7 września przebywał w Kutach, pierwsze informacje o sowieckiej agresji otrzymał o godzinie 6.00 rano. Pierwszą reakcją była decyzja o podjęciu walki. W miarę napływania meldunków Śmigły zdał sobie sprawę, że wobec skali agresji sowieckiej polski opór jest bezsensowny ${ }^{10}$. Trzeźwy zawsze Józef Lipski, do wojny ambasador RP w Berlinie, skonkludował rzeczowo: „to nie wojna - to katastrofa”.

\footnotetext{
ze strażnic KOP i wreszcie doniesienia o prawie 300 sowieckich grupach dywersyjno-sabotażowych aktywizujących się po stronie polskiej w rejonie węzłów komunikacyjnych, mostów, dworców i wiaduktów.

4 Por. M. Kornat, Dyplomacja II Rzeczypospolitej wobec paktu Ribbentrop-Mołotow, „Dzieje Najnowsze”, 32/2000, nr 2, s. 27-28.

5 Dał temu wyraz również podczas konferencji na Zamku 23 VIII. Uważał za logiczne - przyjmując sowiecki punkt widzenia - że Moskwa będzie zachęcać Niemcy do agresji przeciwko Polsce. Por. M. Kornat, Dyplomacja II Rzeczypospolitej..., s. 28; P. Wieczorkiewicz, Historia polityczna Polski 1935-1945, Warszawa 2005, s. 58, 68 i 70.

6 Por. M. Kornat, Dyplomacja II Rzeczypospolitej..., s. 28-29.

7 Tamże.

8 Sowieci uderzyli siłami dwóch frontów. Front Białoruski komandarma II rangi Michaiła Kowaliowa i Front Ukraiński komandarma I rangi Siemiona Timoszenki dysponowały ponad 460 tys. żołnierzy i ok. 5,5 tys. pancernych pojazdów bojowych i ok. 1800 samolotów. Wraz z siłami drugiego rzutu było to milion żołnierzy oraz wojska pogranicza i NKWD. Siły KOP i WP niewiele mogły przeciwstawić. 17 IX we wschodnich województwach mieliśmy ok. 300 tys. żołnierzy oraz 20 batalionów KOP rozrzuconych wzdłuż 1400-kilometrowej granicy z Sowietami i 4 bataliony strzegące granicy z Litwą. Skuteczną walkę mogło podjąć tylko 100 tys. żołnierzy polskich.

9 Por. M. Kornat, Dyplomacja II Rzeczypospolitej..., s. 27.

10 PW t. 10, Sowiecka okupacja, s. 8; W.J. Wysocki, Cień Zawiszy. Ostatnie lata Marszałka Edwarda Śmigłego-Rydza, wyd. 2, Komorów 1991, s. 23.
} 
Dnia I7 września w Kołomyi po otrzymaniu wiadomości z placówki KOP w Czortkowie o agresji sowieckiej gen. Wacław Stachiewicz zanotował: „Ani naczelny wódz, ani nikt z nas oficerów sztabu nie miał najmniejszych wątpliwości, co do charakteru, w jakim Sowiety wkroczyły do Polski. Było dla nas jasne, że dostaliśmy podstępny cios w plecy [...]"'

Tego samego dnia po południu min. Józef Beck nadał telefonogram do konsulatu RP w Czerniowcach, w którym wyraził własną ocenę inwazji sowieckiej: „Założyliśmy w Moskwie protest. Działanie to jest klasycznym przykładem agresji”. W innych instrukcjach dla placówek dyplomatycznych sugerował, że w przyszłości strona polska zwróci się do aliantów o prawno-międzynarodową ocenę agresji sowieckiej.

Także I7 września po południu min. Beck na ręce ambasadora Gheorge Grigorcea złożył deklarację zwalniającą Rumunię ${ }^{\mathrm{I} 2} \mathrm{z}$ obowiązku wypowiedzenia wojny Związkowi Sowieckiemu po jego agresji na Polskę, czyli Polska nie oczekiwała na zastosowanie „casus foederis”. Wszak Rumunię obowiązywała konwencja sojusznicza z I92I r. (kilkakrotnie później odnawiana).

Tegoż dnia po porozumieniu z Prezydentem i Naczelnym Wodzem min. Beck wysłał do placówek zagranicznych komunikat informacyjny i zgłosił formalny protest przeciwko agresji sowieckiej. Polscy ambasadorowie tego dnia wręczyli noty rządom Francji i Anglii. Zabrakło w nich wprost werbalnego stwierdzenia, że w wyniku napaści ZSSR Polska znalazła się w stanie wojny z Moskwą, jednakowoż zaistniał z punktu widzenia prawa międzynarodowego stan wojny polsko-sowieckiej ${ }^{13}$.

I7 września o godzinie I6.30 w Kutach Edward Śmigły-Rydz uczestniczył wraz z prezydentem, premierem i ministrem spraw zagranicznych w redagowaniu orędzia prezydenckiego do narodu ${ }^{14}$. Wieczorem, około godziny 22.00, marszałek wydał dyrektywę: „Sowiety wkroczyły [...]. Z Sowietami nie walczyć [...]"'5. Naczelny Wódz mógł uznać, że w niemal beznadziejnej sytuacji jego głównym zadaniem jest ocalenie jak największej liczby zdolnych do walki jednostek. Stąd wieczorna - a więc już po utracie linii granicznej i pierwszych starciach z siłami sowieckimi - pragmatyczna decyzja o dyrektywie nie podejmowania walki ze wschodnim agresorem ${ }^{16}$.

Zważywszy na kłopoty z łącznością w ostatnich dniach między sztabem Naczelnego Wodza a poszczególnymi jednostkami, zwłaszcza wielkimi jednostkami, dyrektywa marsz. E. Śmigłego-Rydza nie dotarła do wielu formacji wojskowych lub dotarła z wyraźnym opóźnieniem. Tak więc sugestie różnego rodzaju, że dyrektywa była przyczyną rozbrojenia wojsk polskich na wschodnim obszarze Rzeczypospolitej jest nieprawdziwa, nieuprawniona

\footnotetext{
11 W. Stachiewicz, Pisma, t. 2, s. 196-197 - za: M. Jabłonowski, P. Stawecki, Następca Komendanta Edward Śmigly Rydz, Pułtusk-Warszawa 2013, s. 306.

12 Od 6 IX 1939 r. formalnie neutralnej wobec konfliktu polsko-niemieckiego.

13 W.T. Drymmer, W stużbie Polsce, Kraków 2014, s. 285.

14 „Obywatele! Gdy armia nasza z bezprzykładnym męstwem zmaga się z przemocą wroga od pierwszego dnia wojny aż po dzień dzisiejszy wytrzymując opór ogromnej przewagi całości bez mała niemieckich sił zbrojnych, nasz sąsiad wschodni najechał nasze ziemie, gwałcąc obowiązujące umowy i odwieczne zasady moralności. Stanęliśmy tedy nie po raz pierwszy w naszych dziejach w obliczu nawałnicy, zalewającej nasz kraj z zachodu i wschodu."

15 M. Jabłonowski, P. Stawecki, Następca Komendanta..., s. 306-307.

16 Dyrektywa marsz. E. Śmigłego-Rydza w swej formie ideowej przetrwała niemal przez całą wojnę, choć sam jej autor przestał być Naczelnym Wodzem jesienią 1939 r. Oficjalnie będzie podtrzymywana przez konstytucyjne organa państwa polskiego, włącznie z jego siłami zbrojnymi (AK) w kraju.
} 
i nieracjonalna. Dowódcy mogli się wahać w nocy, rankiem i przez cały I7 września, ale nie po godzinie 22.00, gdy dyrektywę rozesłano ${ }^{17}$.

Dyrektywa marsz. Śmigłego-Rydza miała o wiele większe znaczenie na południu niż w północno-wschodniej Rzeczypospolitej. Tu z powodu lepszej komunikacji treść dyrektywy dotarła szerzej do dowódców, a polecenie wycofania się na Węgry i do Rumunii było łatwiejsze. Zaniechanie oporu na przedmościu rumuńskim nie zostało ogólnie dobrze przyjęte przez sporą część korpusu oficerskiego. Były wszak jednostki walczące z agresorem ze Wschodu z pełną konsekwencją, jak choćby pułki/bataliony KOP „Równe” i „Czortków”, które stawiły opór na równi Sowietom, jak i bandom ukraińskim. Liczono też, że ,zbrojną demonstracją, protest wobec świata przeciw podstępnej agresji ZSSR wyrażą strzały cofających się oddziałów KOP"ı.

Reakcje polityczne na wiadomość o agresji sowieckiej pierwszego dnia ograniczyły się do komunikatu protestującego sygnowanego przez premiera Sławoja Felicjana Składkowskiego oraz zdecydowanej instrukcji ministra spraw zagranicznych J. Becka piętnującej inwazję sowiecką jako „,akt niesprowokowanej agresji”. Najważniejsze było jednak orędzie Prezydenta RP Ignacego Mościckiego do narodu polskiego tego dnia rozesłane z Kut. I8 września w godzinach rannych z konsulatu w Czerniowcach z terytorium Rumunii powtórnie nadano tekst orędzia prezydenckiego, co władze w Bukareszcie uznały za akt pogwałcenia neutralności swego kraju.

Władze najwyższe Rzeczypospolitej, mimo szeregu oświadczeń, protestów, orędzia prezydenta, w chaosie wydarzeń I7 września wprawdzie nie stwierdzały jednoznacznie i wprost stanu wojny między Polską a Związkiem Sowieckim, choć agresor sowiecki pogwałcił wszelkie umowy dwustronne z Polską (z paktem o nieagresji z I932 r. na czele) oraz wiążące go umowy międzynarodowe ${ }^{19}$.

17 Tylko w nielicznych wypadkach lokalni dowódcy (i wysocy urzędnicy) zakazywali walki z Sowietami w każdej sytuacji. Takie niechlubne przypadki to: gen. Mieczysław Smorawiński, dowódca Okręgu Korpusu nr II w Lublinie, płk Jan Skorobohaty-Jakubowski, gen. bryg. Leon Bilewicz, Stanisław Widacki, prezydent Tarnopola, który apelował, by powitać sowieckie wojska (choć nie uchroniło to jego i innych od kresu w dołach katyńskich). Gen Władysław Langner, dowódca obrony Lwowa, dyrektywę w pełnym brzmieniu zachował tylko do swojej wiadomości. Swoim oficerom część o stawianiu oporu w przypadkach natarcia Sowietów i prób rozbrojenia naszych oddziałów zataił. Utrącił także plan przebicia się sił lwowskich ku granicy węgierskiej (plan sztabu 35 DP), choć szanse na taką akcję były niemałe.

18 Z Sowietami walczyły bataliony KOP Sarny, Głębokie, Krasne, Iwieniec, Kleck, Baranowicze, a także brygada KOP Polesie, marynarze Flotylli Pińskiej. Argumentem realnej wojny były też straty. We wrześniowych walkach z Sowietami zginęło 3-3,5 tys. polskich wojskowych i cywilów (wg. innych danych: 6-7 tys. poległych i pomordowanych), ok. 20 tys. rannych i uznanych za zaginionych. Bandy ukraińskie zamordowały ok. 1400 Polaków. Do niewoli sowieckiej dostało się ok. 240-250 tys. żołnierzy WP, KOP, funkcjonariuszy Policji Państwowej. Po stronie sowieckiej zginęło 2,5-3 tys., 6-7 tys. rannych, stracili 150 wozów bojowych i do 20 samolotów. Wziętych do niewoli nazywali wprost: wojenno plennymi czyli jeńcami wojennymi, tylko w propagandzie peerelowskiej używano nagminnie, iż byli to ,internowani”. Por. też: Polskie Sity Zbrojne w Drugiej Wojnie Światowej, t. 1: Kampania Wrześniowa, cz. 4, Londyn 1986, s. 525-526.

19 Umowę traktatową w sensie bilateralnym poszerzały: - pakt o nieagresji z VII 1932 r.; - protokół prolongacyjny z V 1934 r. (przedłużający pakt do 1945 r.). W sensie międzynarodowym wielostronnym następstwem były umowy: - pakt Brianda-Kelloga z VIII 1928 r.; - tzw. protokół moskiewski z II 1929 r. (o regionalnym wejściu życie paktu Brianda-Kelloga); - londyńska deklaracja o definicji agresora z VII 1933 r.; - wspólne członkostwo w Lidze Narodów. Por. M. Gmurczyk-Wrońska, Negocjacje polsko-sowieckie o pakt o nieagresji w roku 1927 i w latach 1931-1932, „Dzieje Najnowsze”, 2012, z. 3, s. 21-51; S. Zabiełło, O rzad i granice. Walka dyplomatyczna o sprawe polska w II wojnie światowej, wyd. 4, Warszawa 1986, passim; J. Łojek [Leopold Jerzewski], Agresja 17 września 1939. Studium aspektów politycznych, wyd. 3, Warszawa 1990, s. 19-20. 
Skoro formalnie ZSSR nie wypowiedział Polsce wojny, a strona polska nie dążyła do jednoznacznego prawnego precyzowania sytuacji politycznej, toteż I9 września 1939 r. polski komunikat prasowy potwierdzał bezradność władz Rzeczypospolitej: „Wobec oświadczenia o neutralności sowieckiej armia polska nie prowadzi działań wojennych przeciw armii sowieckiej, natomiast rząd polski złożył protest przeciw naruszeniu granicy"º.

Czyżby rzeczywiście zabrakło aktu formalnego w postaci stwierdzenia stanu wojny ze Związkiem Sowieckim?! Czyżby dokumenty oficjalne nie mówiły o fakcie wojny; czy najazd, napad, przemoc, agresja... to nie synonimy stanu wojny?! Miało to jednak doniosłe skutki prawne i propagandowe, i gdy doszło później do rozmów z Moskwą, strona polska godząc się na interpretację strony przeciwnej - była w sytuacji niedogodnej, co świetnie wykorzystali Sowieci.

Po ratyfikacji tajnego protokołu z 23 września 1939 r. kolejnej antypolskiej zmowy Hitlera i Stalina w postaci „traktatu o przyjaźni i granicy” (ratyfikacja nastąpiła 25 września) polscy ambasadorowie w imieniu rządu Rzeczypospolitej 30 września wręczyli rządom państw sojuszniczych notę następującej treści: „W obliczu ciężkiego pogwałcenia świętych praw Państwa Polskiego i narodu polskiego, dokonanego przez umowę z dnia 28 września między Niemcami a Związkiem Socjalistycznych Republik Rad [raczej: Związkiem Socjalistycznych Sowieckich Republik], dysponującymi ziemiami Rzeczypospolitej Polskiej na rzecz obydwu państw agresorów, zakładam w imieniu Rządu Polskiego najbardziej formalny i uroczysty protest przeciwko tej uknutej zmowie między Berlinem i Moskwą, wyzutej ze wszystkich zobowiązań międzynarodowych i całej moralności ludzkiej. Polska nigdy nie uzna tego aktu przemocy i, wobec słuszności swej sprawy, nie przerwie walki aż do dnia, kiedy jej ziemie zostaną oswobodzone od okupantów i jej prawa legalne zostaną calkowicie restytuowane [pogrub. WJW]. Przez heroiczny opór swej armii, przez poświęcenie patriotyczne całej ludności, przejawiające się w bohaterskiej obronie swej stolicy Warszawy, Lwowa, Wilna, Gdyni, Modlina i tylu innych miast, naród polski jasno wykazał światu swą niezłomną wolę do życia wolnego i niepodległego. Opierając się na jednomyślnych sympatiach krajów, respektujących wolność i dobrą wiarę w stosunkach między narodami, i ufając w stałe poparcie, które gwarantują jej umowy przymierza, Polska będzie kontynuować walkę wszelkimi będącymi w jej rozporządzeniu środkami, wierząc, wierząc w swą przyszłość i ostateczne zwycięstwo".

Równorzędność obu agresorów-okupantów i determinacja walki z nimi potwierdza wcześniejsze dokumenty władz polskich odnośnie stanu stosunków z Niemcami i Sowietami. Jednocześnie to polskie władze utrudniały jednoznaczne zdefiniowanie swoich relacji ze Związkiem Sowieckim. Dotyczy to w największym stopniu rządu gen. Władysława Sikorskiego (także Naczelnego Wodza), którego gabinet po dłuższych dyskusjach przyjął, że pomiędzy obu państwami istnieje stan wojny de facto. Jednakże ogłoszenie publiczne tej konstatacji okazało się formalnie niemożliwe, bo mogło wywołać niebywałe komplikacje na arenie międzynarodowej, czyli brak akceptacji takiego stanu rzeczy przez sojuszników, co tłumaczył min. Zaleski jako narażenie rządu na pewna śmieszność. Faktycznie oznaczało to wyzbycie się przez powrześniowy rząd polski - już od jesieni 1939 r. - suwerenności.

20 Por. M. Turlejska, Prawdy i fikcje. Wrzesień 1939 - grudzień 1941, wyd. 2, Warszawa 1968, s. 121; W.J. Wysocki, Cień Zawiszy..., s. 23. 
Polityka sowiecka wobec Polski była spoza dyplomacji, prawa międzynarodowego i zasad moralności w życiu międzynarodowym. Niestety, po I7 września I939 r. do tych zasad sowieckich dostosowały się państwa zachodnie.

Agresja sowiecka nie była aktem niespodziewanym dla Paryża i Londynu. Tam i w Waszyngtonie postanowiono zareagować tak, aby uniknąć pchnięcia Moskwy ku dalszemu zbliżeniu z III Rzeszą. Oznaczało to, że sojuszniczą Polskę poświecono dla poprawienia relacji z Sowietami. Jednocześnie politycy europejscy, zwłaszcza brytyjscy, nie szczędziliwiarołomnych z polskiego punktu widzenia, bo wbrew zobowiązaniom poczynionych uprzednio wobec nas - gestów wobec Moskwy. Najdalej posunął się najgorzej w pamięci polskiej zapisany David Lloyd George, który wychwalał „wyzwolicielski pochód Armii Czerwonej” i piętnował ,imperialistyczną Polskę".

Należy pamiętać, że Francja od 935 r. miała układ o wzajemnej pomocy z ZSSR oraz włączyła Moskwę w swoje kalkulacje polityczne związane z polityką zbiorowego bezpieczeństwa. Francuzi za wszelką cenę chcieli lokalizować wszystkie konflikty z dala od granic Francji i rola Polski miała stanowić czynnik przejściowy i być sojusznikiem zastępczym po utracie alianta rosyjskiego. Umowę wojskową wiążącą Paryż i Warszawę dzisiaj możemy oceniać $\mathrm{w}$ istocie jako bezwartościową z powody odmowy podpisania przez Francuzów umowy politycznej. Pozwalało to im naciskać na partnera polskiego, choćby w celu przyjęcia sowieckiej ,pomocy” na wypadek ataku niemieckiego, jak też eliminacji osób lojalnych jedynie wobec polskiej racji stanu, a mało układnych i serwilistycznych wobec Francuzów. Ci zaś gotowi byli udzielić gościny tylko takiemu rządowi polskiemu, co do którego Paryż miał nadzieję, że będzie lojalny i dyspozycyjny ${ }^{21}$.

Agresja niemiecka na Polskę został napiętnowana przez polityków i media francuskie, ale inaczej już było z napaścią sowiecką. Przyjęto tezę, iż nie należy zrywać stosunków dyplomatycznych z Moskwą i jak pisał Daladier: „nie zamykać sobie żadnej z dróg, choćby nawet okrężnych, pozostawionych przez Moskwę jako otwarte, i nie zrywać żadnego z istniejących kontaktów, tak długo jak ZSRS z własnej woli nie zajmie miejsca w obozie przeciwnym”22. Strona polska domagała się po I7 września kategorycznego protestu Francji wobec ZSSR, ale Paryż nie zamierzał czynić temu zadośćc ${ }^{3}$.

W 1939 r. sojusznicza Francja nie tylko nie wypełniła zobowiązań wobec Polski; nad Sekwaną liczono, że Francja może odegrać jeszcze rolę w relacjach międzypaństwowych w Europie Środkowej podobną do tej po I wojnie światowej ${ }^{24}$. Sojusz polsko-francuski stracił na znaczeniu we wrześniu 1939 r., zaś po klęsce Francji przestał funkcjonować i nie został reaktywowany. Rząd polski miał podobne oceny z Wolnymi Francuzami i Francuskim Komitetem Wyzwolenia Narodowego gen. Charlesa de Gaulle'a w kwestiach niemieckich, ale różnił się istotnie w ocenie i kontaktach z Sowietami ${ }^{25}$. Nowa Francja powściągliwa

\footnotetext{
21 M. Gmurczyk-Wrońska, W cieniu wielkiej polityki - Rosa Bailly a stosunki francusko-polskie w latach 19161945, (mps w posiadaniu autora), k. 6-9.

22 Por. H. Batowski, Zachód wobec granic Polski 1920-1940. Niektóre fakty mniej znane, Łódź 1995, s. 163 (tam depesza Daladiera do ambasady francuskiej w Moskwie z 16 IX 1939).

23 Tłumaczono, iż brak stosownego zapisu w konwencji wojskowej polsko-francuskiej, iż w przypadku agresji sowieckiej przeciwko Polsce Francja automatycznie wejdzie w stan wojny z Moskwą.

24 M. Gmurczyk-Wrońska, W cieniu..., k. 10.

25 Tamże, k. 12.
} 
była wobec bezprawia dokonanego w Jałcie i nie zajęła jakiegokolwiek stanowiska wobec granicy wschodniej Polski.

W notatce sprawozdawczej ambasadora RP w Wielkiej Brytanii Edwarda Raczyńskiego z londyńskich rozmów lorda Halifaxa i Chamberlaina z ministrem spraw Zagranicznych RP Augustem Zaleskim z I2 października I939 r. czytamy m. in.: „Należy unikać w danej chwili jakiejkolwiek działalności skierowanej przeciw Rosji Sowieckiej, albowiem Rosja nie przeszła jeszcze do obozu Niemiec [sic!] i istnieje nadzieja utrzymania jej w stanie neutralności [pogrub. WJW]. Zaleskiemu oświadczono [ze strony przywódców brytyjskich], że Polacy muszą się zrównać w szeregu z aliantami i z tego szeregu nie wybiegać, prowadząc politykę zgodną z celem aliantów - pokonania Niemiec. [...] Brytyjscy mężowie stanu wyraźnie zaznaczyli Zaleskiemu, że w żadnych warunkach Polska nie może liczyć na to, aby Wielka Brytania wszczęła wojnę przeciw Rosji sowieckiej na rzecz odzyskania przez Polskę tych obszarów, które zostały zajęte przez Sowiety. [...] zajęte przez wojska sowieckie dla względów strategicznych celem zabezpieczenia tej części granicy od strony Niemiec. Obszary te może [pogrub. WJW] będą mogły być zwrócone Polsce w drodze rokowań z Rosją Sowiecką przy okazji przyszłej konferencji pokojowej. Zaleski miał bardzo słabe argumenty, aby się temu stanowisku przeciwstawić [...]"26.

Podczas wizyty w Londynie w dniach I4-20 listopada I939 r. premier Sikorski odbył szereg rozmów. W notatce sprawozdawczej ambasadora Raczyńskiego z prowadzonych przez niego rozmów czytamy: „Sikorskiemu zależało przede wszystkim na dowiedzeniu się od lorda Halifaxa, czy oświadczenie jego w Izbie Lordów z dn. 26 października, że inwazja rosyjska do Polski stanowi jedynie przesunięcie naprzód granicy do linii Curzona, wyobraża oficjalny punkt widzenia Rządu Brytyjskiego. Rząd Polski zgłosił już swe zastrzeżenia przeciwko enuncjacji Halifaxa w liście, skierowanym do niego przez Zaleskiego. Ale wyjaśnienia, jakie Sikorski otrzymał obecnie w Londynie zaspokoiły go całkowicie. [...] ze strony brytyjskiej dano Polakom wyraźnie do poznania, że w Londynie nikt nie zamierza zaostrzać stosunków brytyjsko-sowieckich z racji Polski" ${ }^{27}$.

Stosunek Londynu i... Paryża do Moskwy mógł zmienić się po agresji sowieckiej na Finlandię ${ }^{28}$; reakcja aliantów była w tym wypadku zdecydowanie ostrzejsza. Gen. Sikorski chciał to wykorzystać i przystał na projekt wykorzystania sił polskich (Samodzielnej Brygady Strzelców Podhalańskich płk./gen. Zygmunta Szyszko-Bohusza) w ramach sił ekspedycyjnych brytyjskich i francuskich, gdyż dostrzegł w tym możliwość wciągnięcia aliantów w „faktyczną wojnę” z Rosją, co byłoby z polskiego punktu widzenia ,ze wszech miar pożądane”. W oficjalnych wystąpieniach potępiających napaść Sowietów na Finlandię

\footnotetext{
26 Polska w polityce międzynarodowej (1939-1945). Zbiór dokumentów 1939, Warszawa 1989, s. 593-594.

27 Tamże, s. 617-618. Gen. Sikorski otrzymał za pośrednictwem płk. Jana Kowalewskiego, oficera wywiadu, legendarnego deszyfranta bolszewickich kodów z 1920 r., ,tezy sowieckie” dotyczące stosunku Moskwy do sprawy polskiej. Chodziło o uznanie zaboru ziem wschodnich Rzeczypospolitej w zamian za désinteressement Moskwy wobec Polski etnograficznej. Czy był to sowiecki program wobec Polski?! Jak odpowiedział Sikorski!?

Wydaje się, że odpowiedź była wbrew polskiej racji stanu. Sikorski dostrzegł problemy związane ze sprawą restytucji polskiego stanu posiadania wschodnich obszarów państwa polskiego. Polecił korespondentowi PATa w Londynie, Stefanowi Litauerowi, podejrzewanemu o kontakty z NKWD, opracowanie studium możliwości kompromisu z Moskwą.

28 Pozostaje pytanie, dlaczego Liga Narodów nie uznała zbrodni agresji sowieckiej na Polskę, ale zrobiła to przez wykluczenie ZSSR po jego agresji na Finlandię w XI 1939 r.
} 
gen. Sikorski, stwierdzał, że Rosja idąc na pomoc Niemcom i uderzając na nas w umówionym z nimi momencie nożem w plecy, jest $\mathbf{z}$ nami w stanie wojny na równi z Niemcami ${ }^{29}$.

Deklaracje podówczas składane o relacjach polsko-sowieckich przez polskiego premiera i Naczelnego Wodza były najbardziej jednoznaczne i oczywiste. Później było już mniej jednoznaczności ${ }^{30}$.

Poświadcza to list Juliusza Łukasiewicza, odwołanego przez Sikorskiego ze stanowiska ambasadora RP we Francji, do prezydenta RP Władysława Raczkiewicza z lipca I940 r., w którym czytamy: „Działając bez zgody Prezydenta RP i ministra Spraw Zagranicznych, p. A. Zaleskiego, premier Sikorski udał się I9 czerwca [I940 r.] samolotem do Londynu i tu złożył na własną rękę rządowi angielskiemu memorandum, w którym zaproponował utworzenie po stronie sowieckiej, z ludności ziem polskich, okupowanych przez Armię Czerwona 30.000-nej armii polskiej.

Formalnie i merytorycznie rzecz biorąc, gen. Sikorski, jako premier Rządu Polskiego i Naczelny Wódz, zgłosił w ten sposób paktowania z wrogiem, z którym Polska jest w stanie wojny, i który okupując prawie połowę jej terytorium [pogrub. WJW], znęca się nad naszymi rodakami równie barbarzyńsko jak Niemcy. [...] Nie wolno żadnemu Polakowi, a tym bardziej Naczelnemu Wodzowi i premierowi Rządu na emigracji składać na ręce jakiegokolwiek rządu oświadczeń i dokumentów świadczących o gotowości do paktowania z którymkolwiek z wrogów [...]"3i[ [pogrub. WJW].

Tak reagowali i oceniali sytuację Polacy niepodległościowego ducha, zachowując polską rację stanu, jednakże w kraju - także w kręgach historyków, prawników, polityków etc. narastały wątpliwości wynikłe z niezdolnego do samodzielnego myślenia stanu. Przez okres komunistycznej Polski powtarzana wersja historiografii sowieckiej utrwaliła w zniewolonych umysłach propagandowy stan rzeczy o braku stanu wojny i ,braterskich” relacjach sowiecko-polskich. Fakty temu przeczą - zniewolenie umysłów okazuje się czasem wygodną postawą serwilizmu polskiego wobec Wschodu i... Zachodu. Może to już kompleks polski.!?

\section{Were we at the state of war with the Soviets? Summary}

At the time of the agreement with the German Third Reich on Soviet aggression on Poland on September 17, 1939, the Ambassador of the Republic of Poland in Moscow was given a diplomatic note declaring that in the face of the "break-up of the Polish state" the USSR "is defending the Belarusian and Ukrainian population" in eastern Poland. This deceptive version was "bought" by the Allies of Poland in the West who pretended that Moscow was not a co-hostile against allied Poland. They explained that they didn't want to deepen but to overthrow the German-Soviet alliance. The highest authorities of the Republic of Poland were charged that they were not consistent and did not declare a state of war between Poland

\footnotetext{
29 Andrzej Sowa, Kronika 1939 r., Warszawa 2000, s. nlb. [17 IX].

30 Podczas rozmów Majski - Sikorski sowieccy dyplomaci stwierdzali, że skoro nie było formalnego stanu wojny, to nie może być mowy o okupacji wschodnich ziem Rzeczypospolitej i o przyszłości ich powinien zadecydować plebiscyt ludności po wojnie. Był to szczególny cynizm ze strony Sowietów, gdyż było to już po czystkach etnicznych (deportacjach), zaś zważywszy panujący terror ze strony NKWD i innych formacji sowieckich niemożliwe było rozstrzygnięcie referendalne, jakkolwiek postulat taki był oczywistym bezprawiem.

31 Por. ,Zeszyty Historyczne”, z. 84, Paryż 1988, s. 157-158.
} 
and the USSR from September I7, 1939. This was a game of slander and the author documented the will of the parties to bring such charges. In the period of the Polish People's Republic, the myth of the so-justified Soviet intervention in 1939 was promulgated. Also, today, this issue for many politicians, historians and journalists remains not entirely clear. This text is an analysis of the formation of the basis of this myth, showing its political ground for various propaganda and proclamation of Western states, and ambiguous attitudes of Polish politicians, especially focused on the very naive and politically dependent General Sikorski, the chief of war and prime minister, with greater responsibility - than the ruling party of the Second Polish Republic - for establishing false opinions about Polish-Soviet relations in September 1939.

Keywords: September 1939, Soviet aggression on Poland, Diplomacy of the Second Polish Republic, The Second World War, President Ignacy Mościcki, Marshal Edward Śmigły-Rydz, Minister Józef Beck

Nota o Autorze: Prof. dr hab. Wiesław Jan Wysocki profesor zwyczajny w Instytucie Nauk Historycznych Uniwersytetu Kardynała Stefana Wyszyńskiego. Kierownik katedry XIX i XX wieku oraz kierownik Zakładu badań nad Wychodźstwem Polskim w XIX i XX wieku. 